\title{
URBANISATION, BIRD SPECIES RICHNESS AND ABUNDANCE WITHIN IBADAN METROPOLIS, NIGERIA
}

1. Festus O. Adegbola ${ }^{1}$ (Corresponding Author)

Email address: adegbolafestuso@gmail.com

2. Taiye Adeniyi Adeyanju ${ }^{1}$

Email address: at.adeyanju@ mail1.ui.edu.ng

3. Soladoye B. Iwajomo ${ }^{2}$

Email address: siwajomo@unilag.edu.ng

4. Ibukunoluwa Augustine Ayodele ${ }^{1}$

Email address: profibikunayodele@yahoo.com

1 Department of Wildlife and Ecotourism Management, University of Ibadan, Ibadan, Nigeria

2 Department of Zoology, University of Lagos, Lagos, Nigeria 


\section{ABSTRACT}

4 Urbanisation is considered as one of the most profound threat to wildlife, with habitat 5 loss and fragmentation being predominant. This study assessed the impacts of urbanisation on 6 richness, abundance of bird species within Ibadan metropolis, Nigeria. A uniform grid of 500 7 square meters was installed on the map of Ibadan Metropolis using QGIS to produce 499 grid 8 points distributed across the five urban local governments. 100 grids were selected randomly, 9 identified with mapinR software application and surveyed with 5 point counts within each gird, established at $200 \mathrm{~m}$ interval to avoid double counting. Each point count was observed for 5

11 minutes using a pair of $8 \times 42 \mathrm{~mm}$ binoculars within a $50 \mathrm{~m}$ radius. Habitat variables like number 12 of buildings, trees, paved roads, communication masts were also recorded.

13 A total number of 56 species of birds were observed at the end of the assessment, classified into 1430 families. The test of statistics showed that there was no statistically significant difference in 15 bird species richness between the Local Governments. The test of statistics showed that there 16 was no statistically significant difference in bird species abundance between the local 17 governments. The test of between-subjects effects revealed that there were no statistical 18 significant effects when all the habitat variables were computed in the model on species richness. 19 The number of paved roads and number of vehicles showed a significant effect on bird species 20 abundance while others variables in the model did not exact statistically significant effects on 21 bird species abundance.

22 The study therefore concluded that habitat actions due to urbanisation have not affected the 23 richness and abundance of birds species found in all the local governments. The only habitat 24 variables that have currently exacted significant effect on species abundance within the 25 metropolis are number of vehicles and paved roads.

\section{Word Count: 292}

Keywords: Conservation, Species richness, Species abundance, Urbanisation 


\section{INTRODUCTION}

27 In wildlife conservation and management, there is need for a thorough understanding of the 28 relationships among individual organisms and their environment, as it is important in the development of ecological theories and in the implementation of conservation strategies (Walker et al. 2008). It is general knowledge among environmentalists that there is an increase in the proportion of the earth's surface now converted to human-dominated urban areas; it therefore becomes expedient to understand how urban wildlife communities within these now sophisticated ecosystem types are structured (McKinney 2002). The importance of understanding the ecological effects of urbanisation cannot be under-emphasised, especially with its rapid conversion of previously wild lands around the world. The process associated with urbanisation has profound effects on the distribution of wildlife species and their habitats (Wolff et al. 2018). Urban development is characterised by rapid population growth and profound land use transformation, leading to land conversion, which is a predominant process affecting ecological community structure and population dynamics of living organisms (Hostetler 1997). Research studies show that urban landscapes supports biotic communities in which only a few species increase in density compared to natural areas, resulting in a distinct difference the community diversity between these two landscapes (McKinney 2002).

Developing countries have a large number of wildlife existing outside the protected areas, on farmlands, and in urban areas. Among all wildlife, bird species are largely one of the most common wildlife surviving in urban communities (Gatesire et al. 2015). Birds are one of the most easily studied taxa occurring in cities worldwide as they serve as indicators variables in ecological assessment and monitoring (Magle et al. 2012). Birds are also important in maintaining ecosystems. For example, insectivorous bird species regulate disease vectors including mosquito and rodents. Pied Crow (Corvus albus), contributes to biomass recycling and reduce levels of disposable waste as scavengers. Frugivorous birds play a crucial role in the dispersal of seeds of fruit trees. Sun birds also helps to pollinate plants (Gatesire et al. 2015).

Studies show that bird species in different regions respond to urbanisation in a similar way with 53 most research suggesting that bird communities are negatively impacted by urbanisation (Lin et 54 al. 2011; Sol et al. 2014). There is a general shrinkage in species distribution as urbanisation 55 increases, and the fact that similar bird species can be found in various urban landscape indicates 
56 that urbanisation has a similar effect on local communities of birds irrespective of the region (Lin

57 et al. 2011). As a result of the crucial role birds play in maintaining ecosystems and also support

58 biodiversity, conservationists seek their protection against biological threats and protect the

59 environment efficiently (Gatesire et al. 2015).

60 Primarily the development level, habitat diversity, age and diversity of vegetation present

61 determine the richness of birds in urban areas (McKinney 2002). Native bird species that persists

62 in urban landscapes partly depends on the actions of the landowners because the structural and

63 vegetative characteristics of urban landscapes are largely human-influenced (McCaffrey and

64 Mannan 2012). Urban areas have less assembly of bird species than adjacent natural areas,

65 though some type and level of development support more native bird species than others.

66 According to McKinney (2002), the moderate level of development and vegetation linkable to

67 low density residential areas can support higher densities of some native birds species than other 68 types of urban land use, also including undisturbed sites. 


\section{MATERIALS AND METHODS}

70

71

72

73

74

\section{STUDY AREA}

The study was conducted in Ibadan metropolis, the capital of Oyo State. Ibadan metropolis, covering an area of $129.65 \mathrm{~km}^{2}$, is located in South-Western Nigeria in the southeastern part of Oyo State at about 119 kilometers (74 miles) northeast of Lagos and 120 kilometers (75 miles) east of the Nigerian international border with the Republic of Benin (Popoola and Wahab 2018). Ibadan falls totally within the forest zone but close to the boundary between the forest and the derived savanna. It lies between latitude $3^{\circ} 3^{\prime} \mathrm{N}$ and $4^{\circ} 10^{\prime} \mathrm{N}$ and longitude $7^{\circ} 2^{\prime} \mathrm{E}$ and $7^{\circ} 40^{\prime} \mathrm{E}$. (Popoola and Wahab 2018). The population of Metropolitan Ibadan is 1338659 according to census results for 2006 (Areola and Ikporukpo 2018). There are eleven (11) local governments in Ibadan Metropolitan area consisting of five urban local governments and six semi-urban local governments. The former are: Ibadan South East, Ibadan North East, Ibadan North West, Ibadan South West and Ibadan North Local Government Areas. Ibadan North Local Government has the largest land area among the urban Local Governments, while Ibadan North West is the smallest (Fig. 2). The second largest local government in Urban Ibadan is Ibadan South West. Ibadan metropolis is an important commercial centre and it comprises of people of different cultural and

85 socio-economic backgrounds. General land use pattern of the Ibadan metropolitan area shows a clear distinction purely residential use for Urban Ibadan and agricultural use for semi-urban Ibadan (Salami et al. 2016). 


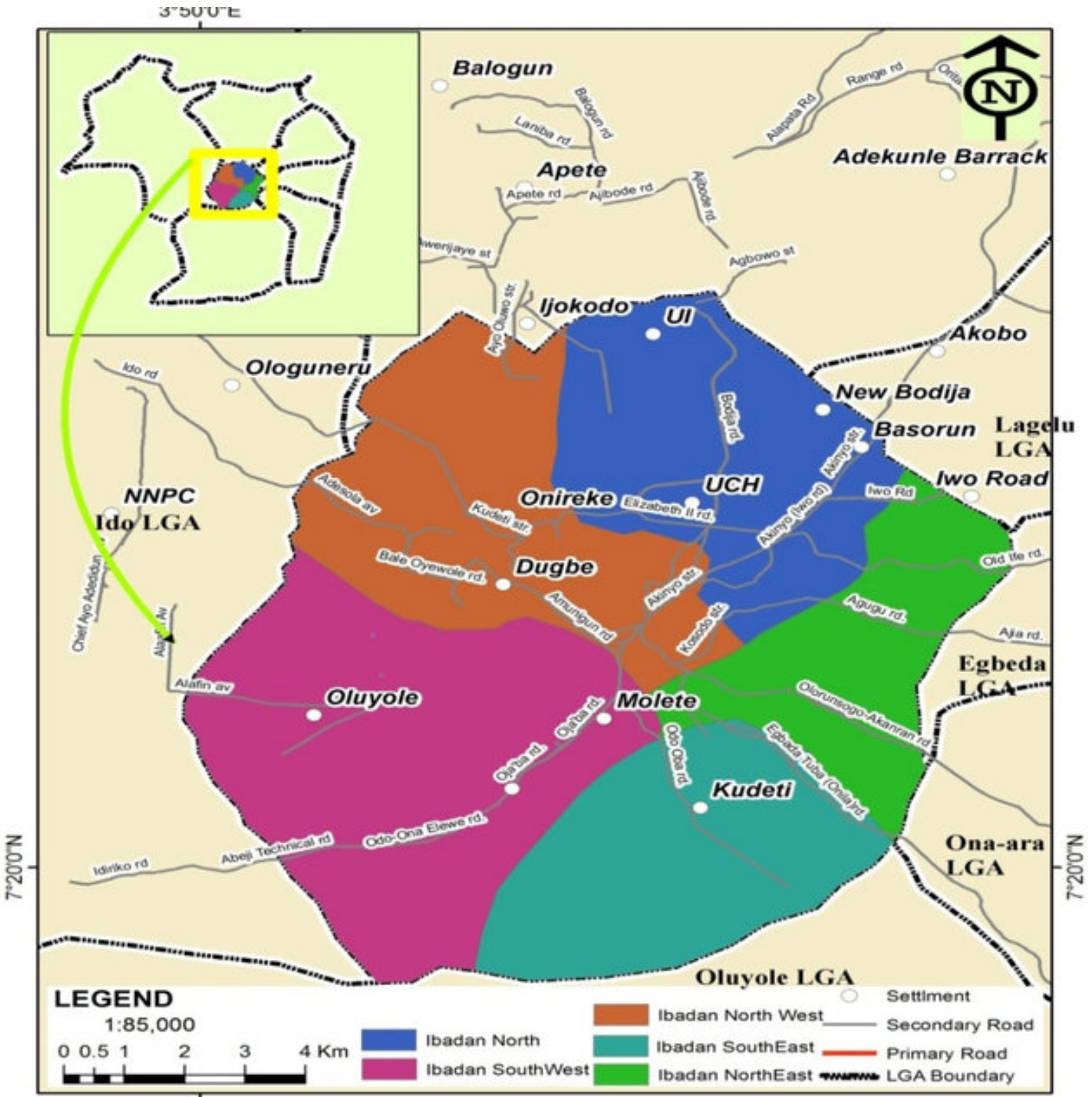

Figure 1: Map of Ibadan Metropolis

91 Source: (Popoola and Wahab 2018) 
bioRxiv preprint doi: https://doi.org/10.1101/2021.05.18.444309; this version posted May 18, 2021. The copyright holder for this preprint (which

was not certified by peer review) is the author/funder, who has granted bioRxiv a license to display the preprint in perpetuity. It is made available under aCC-BY-ND 4.0 International license.

92

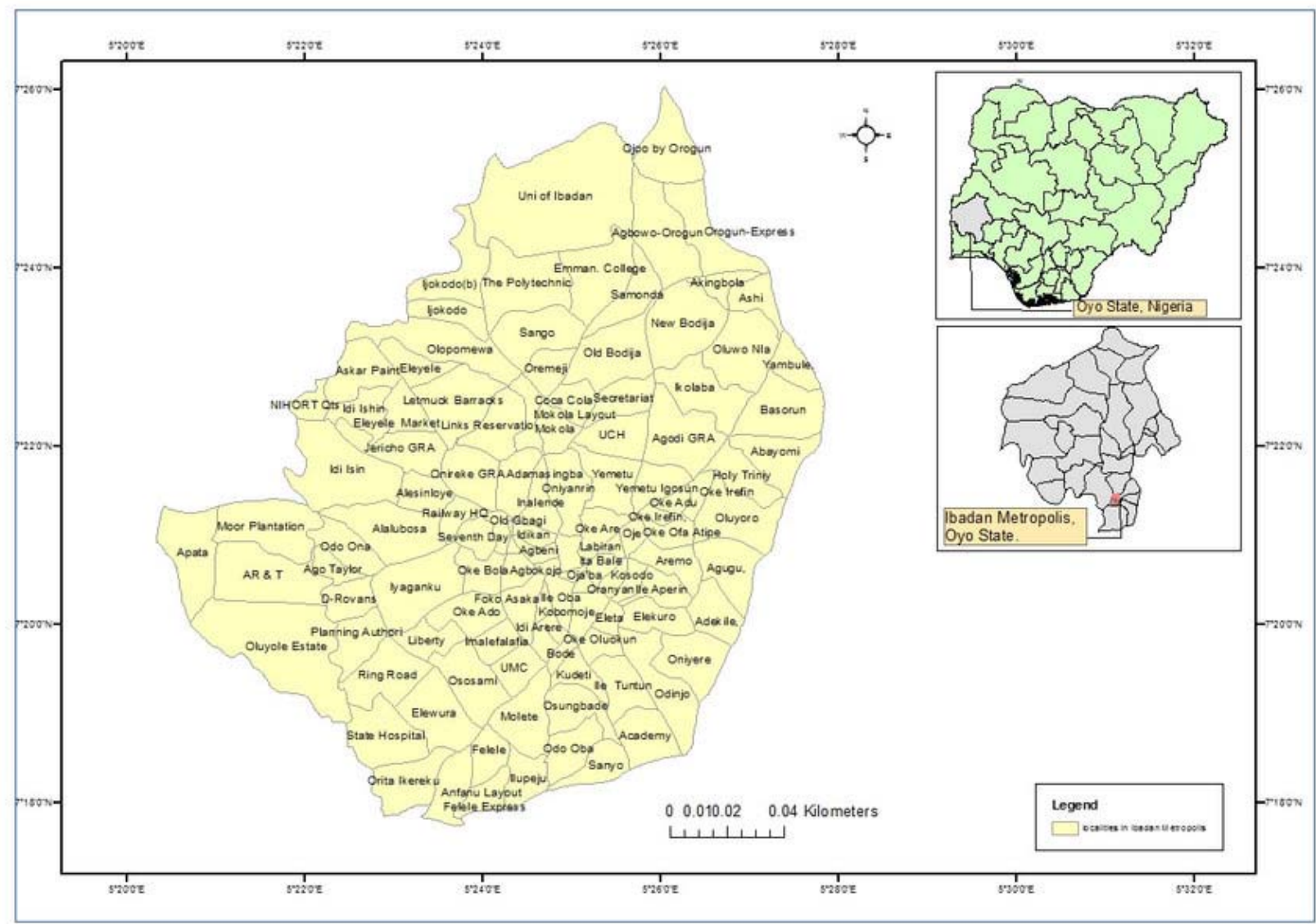

93 Figure 2: Map of Ibadan Metropolis, Oyo State showing communities

94 Source: (Areola and Ikporukpo 2018) 
Using QGIS software application, a uniform grid of 500 by 500 metres was installed on the map

97 of Ibadan Metropolis to produce 499 grids distributed across all the five urban local

98 governments. 100 grids were surveyed with 5 point counts within each gird, established at 200

$99 \mathrm{~m}$ interval to avoid double counting, each point count was observed for 5 minutes within a $50 \mathrm{~m}$

100 radius. Laser range finder was used to delineate the $50 \mathrm{~m}$ radius around each survey point, and to

101 estimate distances to birds. Birds encountered outside the study grids were recorded only when it

102 has never been observed in any of the grids before. When a bird could not be identified in the

103 field, photos from a high resolution camera were taken for later identification by an expert in

104 ornithology. During each visit, a pair of 8x42 mm binoculars was used for sighting birds. Helms

105 field guide to the birds of western Africa (Borrow and Demey 2013) was used to identify the

106 birds; birds call were recorded with a voice recorder and later played back for confirmation. The

107 data were collected between October to December 2020, and observations were done in the

108 morning and evening. Habitat variables recorded for this study, the number of buildings, number

109 of trees, number of communication masts, ground cover, canopy cover, number of pedestrians

110 and vehicles passing within $25 \mathrm{~m}$ radius around the point, describe urban form. No specific

111 permissions were required to conduct this work. All bird surveys were conducted in areas which

112 are open to the public; therefore there was no need to ask land managers for approval 
bioRxiv preprint doi: https://doi.org/10.1101/2021.05.18.444309; this version posted May 18, 2021. The copyright holder for this preprint (which

was not certified by peer review) is the author/funder, who has granted bioRxiv a license to display the preprint in perpetuity. It is made available under aCC-BY-ND 4.0 International license.
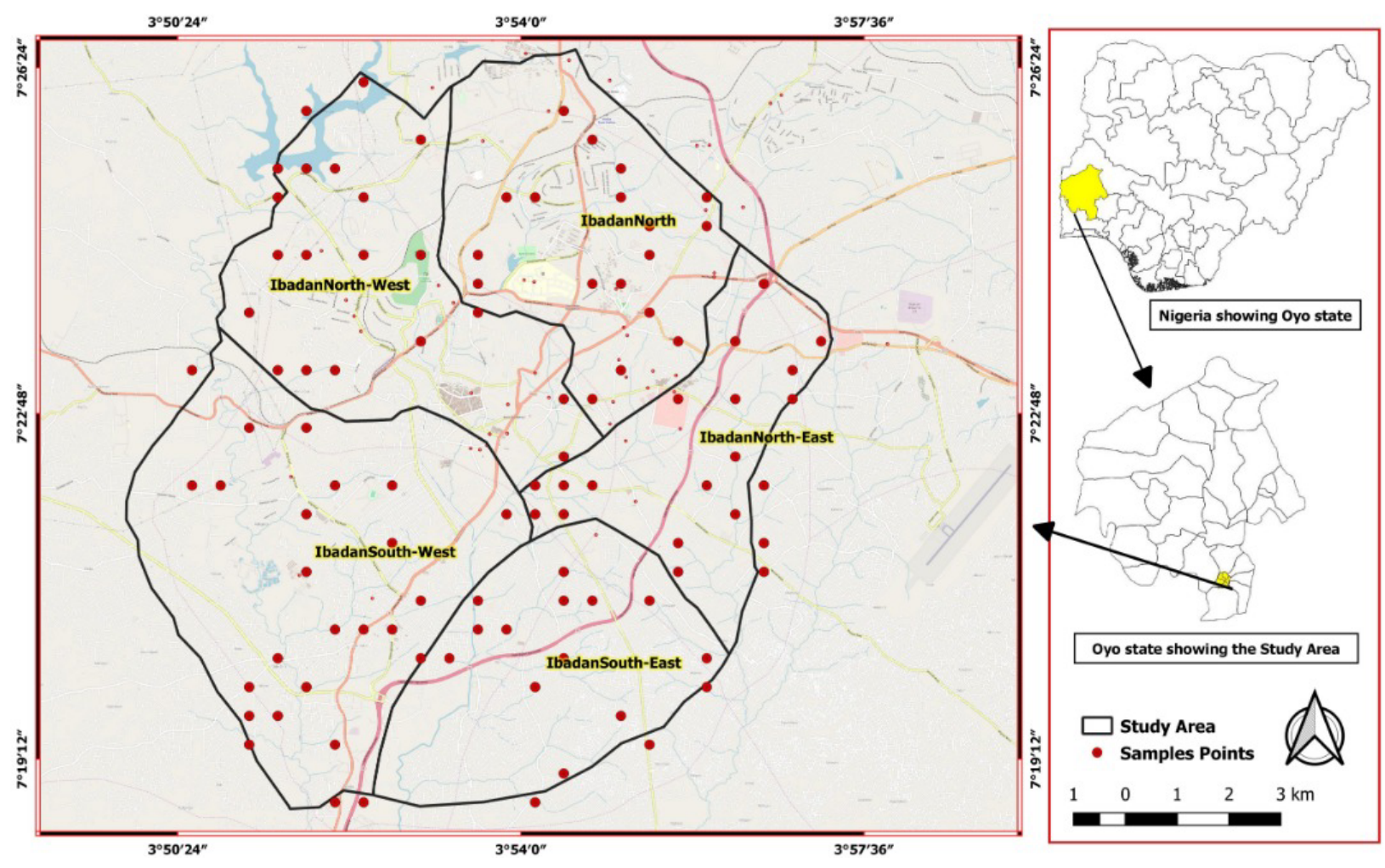

- Figure 3: Map showing survey grids 


\section{DATA ANALYSIS}

119 Species richness and abundance was obtained by counting the total number of species and 120 individual per species respectively as recorded within each grid. The data collected were entered 121 and summarised in Microsoft Excel spread sheet computer software for analysis. Tables and 122 figures were used to represent the results.

123 General Linear models method was fitted in $\mathrm{R}$ statistical package version 3.4 .2 using test of 124 correlation to the determine relationship between the vegetation variables, bird species richness, 125 and bird abundance at 0.05 level of significance. 


\section{RESULTS}

127 This chapter present the results of the data obtained for the purpose of this study. QGIS software application, using a uniform grid of 500 by 500 metres installed across all five selected urban local government in Ibadan was used in collecting the data. General Linear Model (GLM) of statistical analysis was used in analyzing the collected data and testing for statistical significant difference in bird species richness, bird abundance and the habitat variables that determines/ influence bird species richness and its abundance within the metropolis. $(\alpha=0.05)$.

The study observed 56 different species of birds which was grouped into 30 families. (See appendix)

\section{DETERMINATION OF SPECIES RICHNESS WITHIN THE METROPOLIS}

136 Descriptive statistics, Kruskal- Wallis H Test and Post Hoc Test were carried out to determine 137 whether there are statistically significant differences between bird species richness and the five selected urban local government. The local government being the independent variable and bird species observed being the dependent variable.

140 The results showed that mean bird species richness at Ibadan North East, North West, South East 141 and South West were estimated at $8.20 \pm 1.643,10.84 \pm 2.630,8.27 \pm 2.724,9.36 \pm 2.629$ and $14210.54 \pm 5.222$ respectively.

143 On the overall, Bird species richness for Ibadan metropolis was estimated at $9.73 \pm 3.301$. (See 144 table 1a)

145 The Kuskal- Wallis H Test revealed that the mean rank for Ibadan North East is 24.70, Ibadan 146 North is 44.74, Ibadan North West is 25.32, Ibadan South East is $\mathbf{3 4 . 5 5}$ and Ibadan South West is 14736.38 (See table 1b). It implies that mean of Ibadan North will be rank first in bird species 148 richness, followed by Ibadan South West, Ibadan South East, Ibadan North West and Ibadan 149 North East respectively.

150 The test statistics table showed a chi-square value $\left(\boldsymbol{X}^{\mathbf{2}}\right)$ of $\mathbf{8 . 2 5 3}$ and a $\mathrm{p}$-value of $\mathbf{0 . 0 8 3}$. At $5 \%$ 151 C.I., the calculated p-value (0.083) is greater than 0.05. This implies that bird species richness 152 between the different local governments is ns. 
153 Table 1a:

\section{Descriptive Statistics on Species Richness}

154

155

\section{Descriptive Statistics}

156

157 Dependent Variable: Species richness

\begin{tabular}{lccc}
\hline \multicolumn{1}{c}{ Local Government } & N & Mean & Std. Deviation \\
\hline Ibadan North East & 5 & 8.20 & 1.643 \\
Ibadan North & 19 & 10.84 & 2.630 \\
Ibadan North West & 11 & 8.27 & 2.724 \\
Ibadan South East & 22 & 9.36 & 2.629 \\
Ibadan South West & 13 & 10.54 & 5.222 \\
Total & 70 & 9.73 & 3.301 \\
\hline
\end{tabular}

158

159 


\section{Kruskal-Wallis Test Rank}

\begin{tabular}{lcc}
\hline \multicolumn{1}{c}{ Local Government } & N & Mean Rank \\
\hline Ibadan North East & 5 & 24.70 \\
Ibadan North & 19 & 44.74 \\
Ibadan North West & 11 & 25.32 \\
Ibadan South East & 22 & 34.55 \\
Ibadan South West & 13 & 36.38 \\
Total & 70 & \\
\hline
\end{tabular}

162

Test Statistics

Species richness

Chi-Square
Df
Asymp. Sig.
ruskal Wallis Test
ouping variable: local government




\section{Multiple Comparisons}

Dependent Variable: Species richness

Tukey HSD

\begin{tabular}{|c|c|c|c|c|c|c|}
\hline \multirow[b]{4}{*}{ (I) Local government } & & \multirow{4}{*}{$\begin{array}{c}\text { Mean } \\
\text { Difference } \\
\text { (I-J) }\end{array}$} & \multirow{4}{*}{$\begin{array}{l}\text { Std. } \\
\text { Error }\end{array}$} & \multirow[b]{4}{*}{ Sig. } & \multirow{2}{*}{\multicolumn{2}{|c|}{$\begin{array}{c}95 \% \text { Confidence } \\
\text { Interval }\end{array}$}} \\
\hline & & & & & & \\
\hline & & & & & \multirow{2}{*}{$\begin{array}{l}\text { Lower } \\
\text { Bound }\end{array}$} & \multirow{2}{*}{$\begin{array}{l}\text { Upper } \\
\text { Bound }\end{array}$} \\
\hline & & & & & & \\
\hline \multirow[t]{4}{*}{ Ibadan North East } & Ibadan North & -2.64 & 1.628 & .488 & -7.21 & 1.93 \\
\hline & $\begin{array}{l}\text { Ibadan North } \\
\text { West }\end{array}$ & -.07 & 1.747 & 1.000 & -4.97 & 4.83 \\
\hline & Ibadan South East & -1.16 & 1.605 & .950 & -5.67 & 3.34 \\
\hline & $\begin{array}{l}\text { Ibadan South } \\
\text { West }\end{array}$ & -2.34 & 1.704 & .647 & -7.12 & 2.44 \\
\hline \multirow{4}{*}{$\begin{array}{l}\text { Ibadan North Local } \\
\text { Government }\end{array}$} & Ibadan North East & 2.64 & 1.628 & .488 & -1.93 & 7.21 \\
\hline & $\begin{array}{l}\text { Ibadan North } \\
\text { West }\end{array}$ & 2.57 & 1.227 & .235 & -.87 & 6.01 \\
\hline & Ibadan South East & 1.48 & 1.014 & .593 & -1.37 & 4.32 \\
\hline & $\begin{array}{l}\text { Ibadan South } \\
\text { West }\end{array}$ & .30 & 1.166 & .999 & -2.97 & 3.57 \\
\hline \multirow{4}{*}{$\begin{array}{l}\text { Ibadan North West } \\
\text { Local government }\end{array}$} & Ibadan North East & .07 & 1.747 & 1.000 & -4.83 & 4.97 \\
\hline & Ibadan North & -2.57 & 1.227 & .235 & -6.01 & .87 \\
\hline & Ibadan South East & -1.09 & 1.196 & .891 & -4.45 & 2.26 \\
\hline & $\begin{array}{l}\text { Ibadan South } \\
\text { West }\end{array}$ & -2.27 & 1.327 & .437 & -5.99 & 1.46 \\
\hline Ibadan South East & Ibadan North East & 1.16 & 1.605 & .950 & -3.34 & 5.67 \\
\hline
\end{tabular}


bioRxiv preprint doi: https://doi.org/10.1101/2021.05.18.444309; this version posted May 18, 2021. The copyright holder for this preprint (which

was not certified by peer review) is the author/funder, who has granted bioRxiv a license to display the preprint in perpetuity. It is made available under aCC-BY-ND 4.0 International license.

\begin{tabular}{|c|c|c|c|c|c|c|}
\hline \multirow[t]{3}{*}{ Local Government } & Ibadan North & -1.48 & 1.014 & .593 & -4.32 & 1.37 \\
\hline & $\begin{array}{l}\text { Ibadan North } \\
\text { West }\end{array}$ & 1.09 & 1.196 & .891 & -2.26 & 4.45 \\
\hline & $\begin{array}{l}\text { Ibadan South } \\
\text { West }\end{array}$ & -1.17 & 1.133 & .837 & -4.35 & 2.00 \\
\hline \multirow{4}{*}{$\begin{array}{l}\text { Ibadan South West } \\
\text { Local Government }\end{array}$} & Ibadan North East & 2.34 & 1.704 & .647 & -2.44 & 7.12 \\
\hline & Ibadan North & -.30 & 1.166 & 999 & -3.57 & 2.97 \\
\hline & $\begin{array}{l}\text { Ibadan North } \\
\text { West }\end{array}$ & 2.27 & 1.327 & .437 & -1.46 & 5.99 \\
\hline & Ibadan South East & 1.17 & 1.133 & .837 & -2.00 & 4.35 \\
\hline
\end{tabular}

Based on observed means.

The error term is Mean Square (Error) $=10.490$.

167

168 
170 The results in table 4.2a showed that the mean bird abundance and standard deviation was

171 estimated at $64.40 \pm 12.28$ for Ibadan North East, $68.42 \pm 31.39$ for Ibadan North, $46.36 \pm 9.63$

172 for Ibadan North West, $53.68 \pm 24.16$ for Ibadan South East and 65.69 \pm 51.26 Ibadan South

173 West. Overall mean bird abundance and standard deviation is estimated at 59.52 \pm 31.35 .

174 The Kruskal-Wallis Test showed that in term of ranking the abundance of bird species, Ibadan

175 North East will be rank first, followed by Ibadan North, Ibadan North west, Ibadan South east 176 and Ibadan South West respectively. (See table 2b)

177 The test statistics table showed a chi-square value $\left(\mathbf{X}^{\mathbf{2}}\right)$ of $\mathbf{6 . 9 7 3}$ and a p-value of $\mathbf{0 . 1 3 7}$. At 5\% 178 S.L., the calculated p-value is .137; which is greater than 0.05. This implies that bird species 179 abundance between the different local governments is ns.

180 The multiple comparisons table showed that were no statistically significant differences in bird 181 species abundance between any of the selected local government, as p-value in all the 182 comparison are greater than $5 \%$. (See table 2c) 


\section{Table 2a: Descriptive Statistics on species abundance}

184

185

Descriptive Statistics

186

187 Dependent Variable: Species abundance

\begin{tabular}{lccc}
\hline \multicolumn{1}{c}{ Local Government } & N & Mean & Std. Deviation \\
\hline Ibadan North East & 5 & 64.4000 & 12.28007 \\
Ibadan North & 19 & 68.4211 & 31.39058 \\
Ibadan North West & 11 & 46.3636 & 9.63611 \\
Ibadan South East & 22 & 53.6818 & 24.16291 \\
Ibadan South West & 13 & 65.6923 & 51.26465 \\
Total & 70 & 59.5286 & 31.35571 \\
\hline
\end{tabular}




\section{Kruskal-Wallis Test Rank}

\begin{tabular}{lcc}
\hline \multicolumn{1}{c}{ Local Government } & N & Mean Rank \\
\hline Ibadan North East & 5 & 47.00 \\
Ibadan North & 19 & 42.79 \\
Ibadan North West & 11 & 26.27 \\
Ibadan South East & 22 & 32.18 \\
Ibadan South West & 13 & 33.85 \\
Total & 70 & \\
\hline
\end{tabular}

Test Statistics

Species abundance

\begin{tabular}{cc}
\hline Chi-Square & 6.973 \\
Df & 4 \\
Asymp. Sig. & .137 \\
\hline
\end{tabular}

a. Kruskal Wallis Test

b. grouping variable: local government 


\section{Multiple Comparisons}

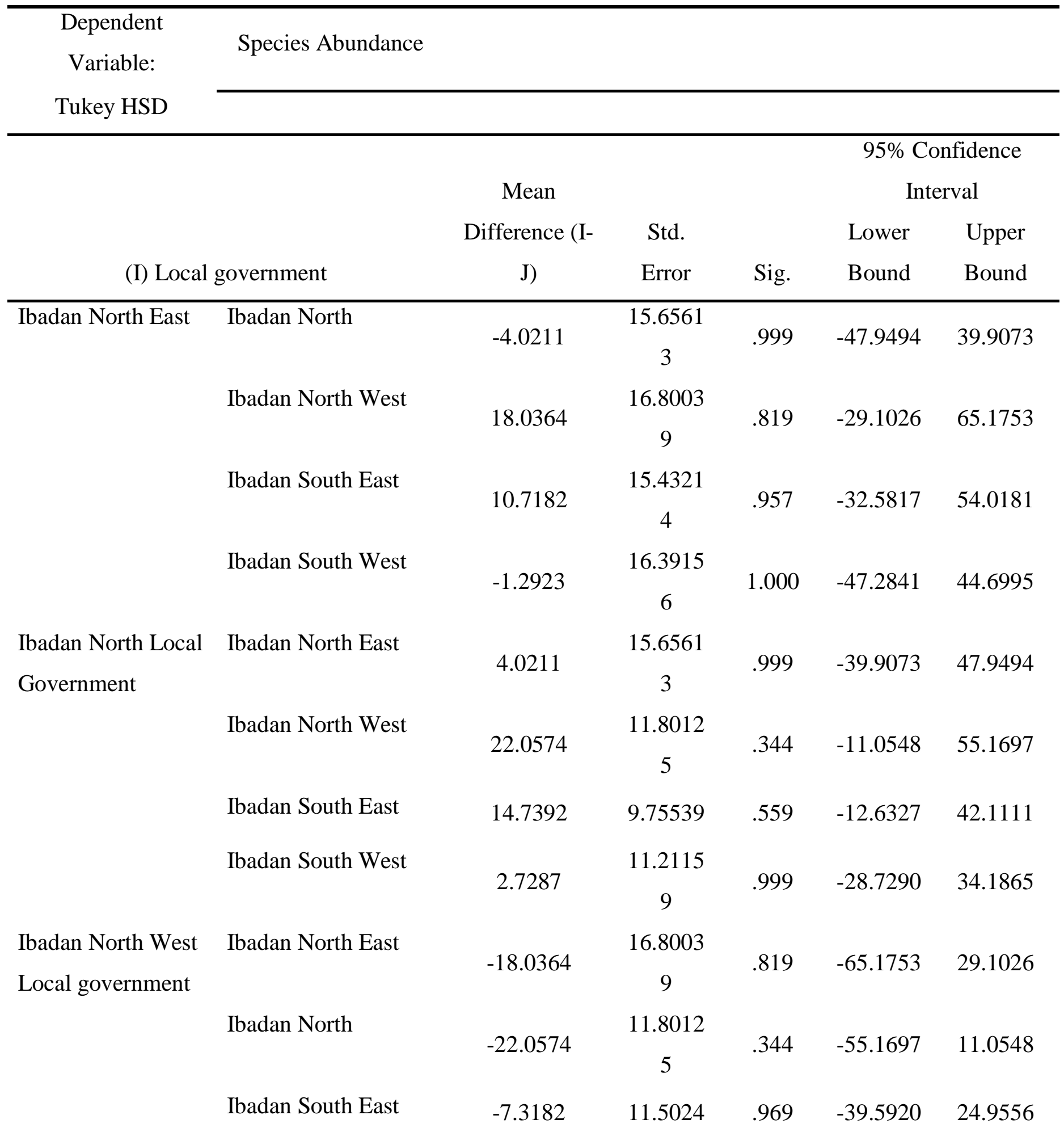


Ibadan South West

$-19.3287$

Ibadan South East Ibadan North East

Local Government

Ibadan North
Ibadan North West

Ibadan South West

$-12.0105$

Ibadan South West Ibadan North East

Local Government

Ibadan North

$-2.7287$

Ibadan North West

19.3287

Ibadan South East

$-10.7182$

$-14.7392$

7.3182
12.7608

1

.557

$-55.1333 \quad 16.4759$

15.4321

9.75539

.559

$-42.1111$

12.6327

11.5024

4

$.969 \quad-24.9556$

39.5920

10.8966

2

$.805 \quad-42.5845$

18.5635

16.3915

6

$1.000 \quad-44.6995$

47.2841

11.2115

$.999 \quad-34.1865$

28.7290

9

12.7608

1

$.557 \quad-16.4759$

55.1333

10.8966

12.0105

Based on observed means.

The error term is Mean Square $($ Error $)=970.245$.

195 

RICHNESS WITHIN IBADAN METROPOLIS

The test of between-subjects effects in table 3 showed whether the habitat variables (independent variables) are statistically significant in assessing and influencing bird species richness within Ibadan Metropolis.

The results revealed that there was no statistically significant relationship between the effect of the number of buildings on bird species richness, $\mathbf{F}(\mathbf{1}, \mathbf{5 4})=\mathbf{0 . 0 7 5}, \mathbf{p}=\mathbf{0 . 7 8 6}$; there was no statistically significant relationship between the effects of the number of trees on bird species richness, $\mathbf{F}(\mathbf{1}, \mathbf{5 4})=\mathbf{0 . 4 5 0}, \mathbf{p}=\mathbf{0 . 5 0 5}$; there was no statistically significant relationship between the effects of the number of masts on bird species richness, $\mathbf{F}(\mathbf{1}, \mathbf{5 4})=\mathbf{0 . 3 2 3}, \mathbf{p}=\mathbf{0 . 5 7 2}$; there was no statistically significant relationship between the effects of the number of paved roads on bird species richness, $\mathbf{F}(\mathbf{1}, \mathbf{5 4})=\mathbf{0 . 8 0 8}, \mathbf{p}=\mathbf{0 . 3 7 3}$; there was no statistically significant relationship between the effects of the number lawns on bird species richness, $\mathbf{F}(\mathbf{1}, \mathbf{5 4})=\mathbf{0 . 0 9 0}$, $\mathbf{p}=\mathbf{0 . 7 6 6}$; there was no statistically significant relationship between the effects of the percentage of canopy covers on bird species richness, $F(\mathbf{1}, \mathbf{5 4})=\mathbf{0 . 3 6 0}, \mathbf{p}=\mathbf{0 . 8 8 1}$; there was no statistically significant relationship between the effects of the percentage of ground covers on bird species richness, $\mathbf{F}(\mathbf{1}, \mathbf{5 4})=\mathbf{0 . 0 4 3} \mathbf{p}=\mathbf{0 . 8 3 6}$; there was no statistically significant relationship between the effects of the presence of farm land on bird species richness, $\mathbf{F}(\mathbf{1 , 5 4 )}$ $=\mathbf{0 . 3 0}, \mathbf{p}=\mathbf{0 . 8 6 3}$; there was no statistically significant relationship between the effects of the number of vehicles on bird species richness, $\mathbf{F}(\mathbf{1}, \mathbf{5 4})=7.437, \mathbf{p}=\mathbf{0 . 0 9}$; there was no statistically significant relationship between the effects of the number of pedestrians on bird species richness, $\mathbf{F}(\mathbf{1}, \mathbf{5 4})=\mathbf{2 . 7 4 4}, \mathbf{p}=\mathbf{0 . 1 0 3}$; there was no statistically significant relationship between the effects of the number of nests on bird species richness, $\mathbf{F}(\mathbf{1}, \mathbf{5 4})=\mathbf{0 . 5 1 7}, \mathbf{p}=\mathbf{0 . 4 7 5}$.

Also, $\mathbf{R}$ square of $\mathbf{3 2 . 9 \%}$ implies that all the independent variables are not too strong in predicting or influencing model.

We can therefore conclude that there were no statistically significant interaction between all the habitat parameters/variables and bird species richness within Ibadan Metropolis. That is all the habitat parameters/ variables did not influence bird species richness within Ibadan. 
$224 \quad$ Table 3: $\quad$ Test of between- Subjects Effects on Species Richness and habitat variables

\begin{tabular}{|c|c|c|c|c|c|}
\hline Source & $\begin{array}{c}\text { Type III Sum } \\
\text { of Squares }\end{array}$ & df & Mean Square & $\mathbf{F}$ & $\begin{array}{l}\text { Sig. (p- } \\
\text { value) }\end{array}$ \\
\hline Corrected Model & $247.093^{\mathrm{a}}$ & 15 & 16.473 & 1.762 & .066 \\
\hline Intercept & 317.361 & 1 & 317.361 & 33.952 & .000 \\
\hline Number of Buildings & .698 & 1 & .698 & .075 & .786 \\
\hline Number of Trees & 4.202 & 1 & 4.202 & .450 & .505 \\
\hline Number of Masts & 3.020 & 1 & 3.020 & .323 & .572 \\
\hline Number of Paved & 7.556 & 1 & 7.556 & .808 & .373 \\
\hline Number of Lawns & .838 & 1 & .838 & .090 & .766 \\
\hline $\begin{array}{l}\text { Percentage of Canopy } \\
\text { cover }\end{array}$ & 3.362 & 1 & 3.362 & .360 & .551 \\
\hline $\begin{array}{l}\text { Percentage of Ground } \\
\text { cover }\end{array}$ & .405 & 1 & .405 & .043 & .836 \\
\hline Presence of farmland & .280 & 1 & .280 & .030 & .863 \\
\hline Number of vehicles & 69.511 & 1 & 69.511 & 7.437 & .009 \\
\hline Number of Pedestrians & 25.651 & 1 & 25.651 & 2.744 & .103 \\
\hline Number of nests & 4.831 & 1 & 4.831 & .517 & .475 \\
\hline Error & 504.750 & 54 & 9.347 & & \\
\hline Total & 7377.000 & 70 & & & \\
\hline Corrected Total & 751.843 & 69 & & & \\
\hline
\end{tabular}

226 R Squared $=.329($ Adjusted R Squared $=.142)$ 

ABUNDANCE WITHIN IBADAN METROPOLIS

The results revealed that there was no statistically significant interaction between the effect of the number of buildings on bird species richness, $\mathbf{F}(\mathbf{1}, \mathbf{5 4})=\mathbf{0 . 2 0}, \mathbf{p}=\mathbf{0 . 8 8 8}$; there was no statistically significant interaction between the effects of the number of trees on bird species richness, $\mathbf{F}(\mathbf{1}, \mathbf{5 4})=\mathbf{2 . 1 8 1}, \mathbf{p}=\mathbf{0 . 1 4 5}$; there was no statistically significant interaction between the effects of the number of masts on bird species richness, $\mathbf{F}(\mathbf{1}, \mathbf{5 4})=\mathbf{0 . 3 5 9}, \mathbf{p}=\mathbf{0 . 5 5 2}$; there was statistically significant interaction between the effects of the number of paved roads on bird species richness, $\mathbf{F}(\mathbf{1}, \mathbf{5 4})=\mathbf{5 . 6 3 2}, \mathbf{p}=\mathbf{0 . 0 2 1}$; there was no statistically significant interaction between the effects of the number of lawns on bird species richness, $F(\mathbf{1}, \mathbf{5 4})=\mathbf{1 . 4 0 8}, \mathbf{p}=$ 0.241; there was no statistically significant interaction between the effects of the percentage of canopy covers on bird species richness, $F(1,54)=1.412 p=0.240$; there was no statistically significant interaction between the effects of the percentage of ground cover on bird species richness, $\mathbf{F}(\mathbf{1}, \mathbf{5 4})=\mathbf{0 . 0 1}, \mathbf{p}=\mathbf{0 . 9 8 1}$; there was no statistically significant interaction between the effects of the presence of farm land on bird species richness, $\mathbf{F}(\mathbf{1}, \mathbf{5 4})=\mathbf{0 . 1 0 0}, \mathbf{p}=\mathbf{0 . 7 5 4}$; there was statistically significant interaction between the effects of the number of vehicles on bird species richness, $\mathbf{F}(\mathbf{1}, \mathbf{5 4})=\mathbf{5 . 0 4 2}, \mathbf{p}=\mathbf{0 . 0 2 2}$; there was no statistically significant interaction between the effects of the number of pedestrians on bird species richness, $\mathbf{F}(\mathbf{1}, \mathbf{5 4})=$ 0.302, $\mathbf{p}=\mathbf{0 . 5 8 5}$; there was no statistically significant interaction between the effects of the number of nests on bird species richness, $\mathbf{F}(\mathbf{1}, \mathbf{5 4})=\mathbf{0 . 4 1 9}, \mathbf{p}=\mathbf{0 . 5 2 0}$. The results revealed that there were statistically significant interaction between the number of paved and the number of vehicles on the bird species abundance and no statistically significant interaction in all other habitat variables/parameters. (See table 4)

Also, $\mathrm{R}$ square of $26.2 \%$ implies that the independent variables are weak in predicting or influencing bird species abundance. significant effect on bird species abundance while all other habitat variables do not exact significant influence on bird species abundance within Ibadan Metropolis. That is, all other habitat parameters/ variables did not influence bird species abundance, except numbers of paved 256 roads and vehicles available within Ibadan metropolis. 
257 Table 4: Test of between- Subjects Effects on Species Abundance and Habitat 258 Variables

Test of Between- Subjects Effects

\begin{tabular}{lccccc}
\hline \multicolumn{1}{c}{ Source } & $\begin{array}{c}\text { Type III Sum } \\
\text { of Squares }\end{array}$ & df & Mean Square & F & $\begin{array}{c}\text { Sig. ( p - } \\
\text { value) }\end{array}$ \\
\hline \multicolumn{1}{c}{ Corrected Model } & 17805.715 & 15 & 1187.048 & 1.281 & .246 \\
\multicolumn{1}{c}{ Intercept } & 5930.968 & 1 & 5930.968 & 6.401 & .014 \\
\multicolumn{1}{c}{ Number of Buildings } & 18.417 & 1 & 18.417 & .020 & .888 \\
Number of Trees & 2027.731 & 1 & 2027.731 & 2.188 & .145 \\
Number of Masks & 332.432 & 1 & 332.432 & .359 & .552 \\
Number of Paved & 5218.020 & 1 & 5218.020 & 5.632 & .021 \\
Number of Lawns & 1304.756 & 1 & 1304.756 & 1.408 & .241 \\
Number of Canopy cover & 1308.209 & 1 & 1308.209 & 1.412 & .240 \\
Number of Ground cover & .531 & 1 & .531 & .001 & .981 \\
Presence of farmland & 92.273 & 1 & 92.273 & .100 & .754 \\
Number of vehicles & 5135.375 & 1 & 5135.375 & 5.542 & .022 \\
Number of Pedestrians & 279.845 & 1 & 279.845 & .302 & .585 \\
Number of nests & 388.402 & 1 & 388.402 & .419 & .520 \\
Error & 50033.728 & 54 & 926.551 & & \\
Total & 315895.000 & 70 & & & \\
Corrected Total & 67839.443 & 69 & & & \\
\hline
\end{tabular}




\subsection{PICTURES OF BIRDS SPECIES AND ACTIVITY SIGHTED IN URBAN AREAS}

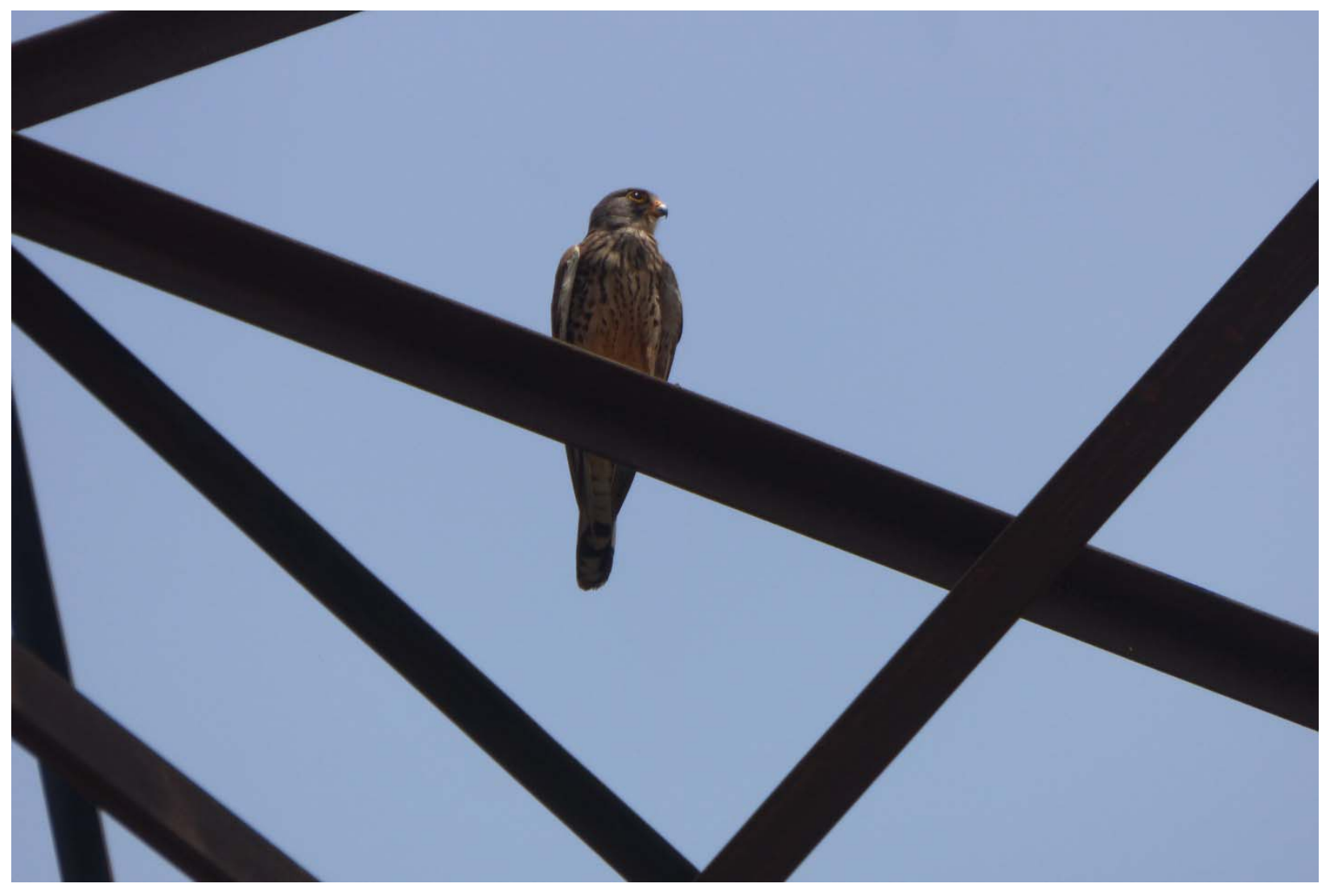

264 Figure 4: Common Kestrel (Falco tinnunculus) resting on a billboard 
bioRxiv preprint doi: https://doi.org/10.1101/2021.05.18.444309; this version posted May 18, 2021. The copyright holder for this preprint (which was not certified by peer review) is the author/funder, who has granted bioRxiv a license to display the preprint in perpetuity. It is made available under aCC-BY-ND 4.0 International license.

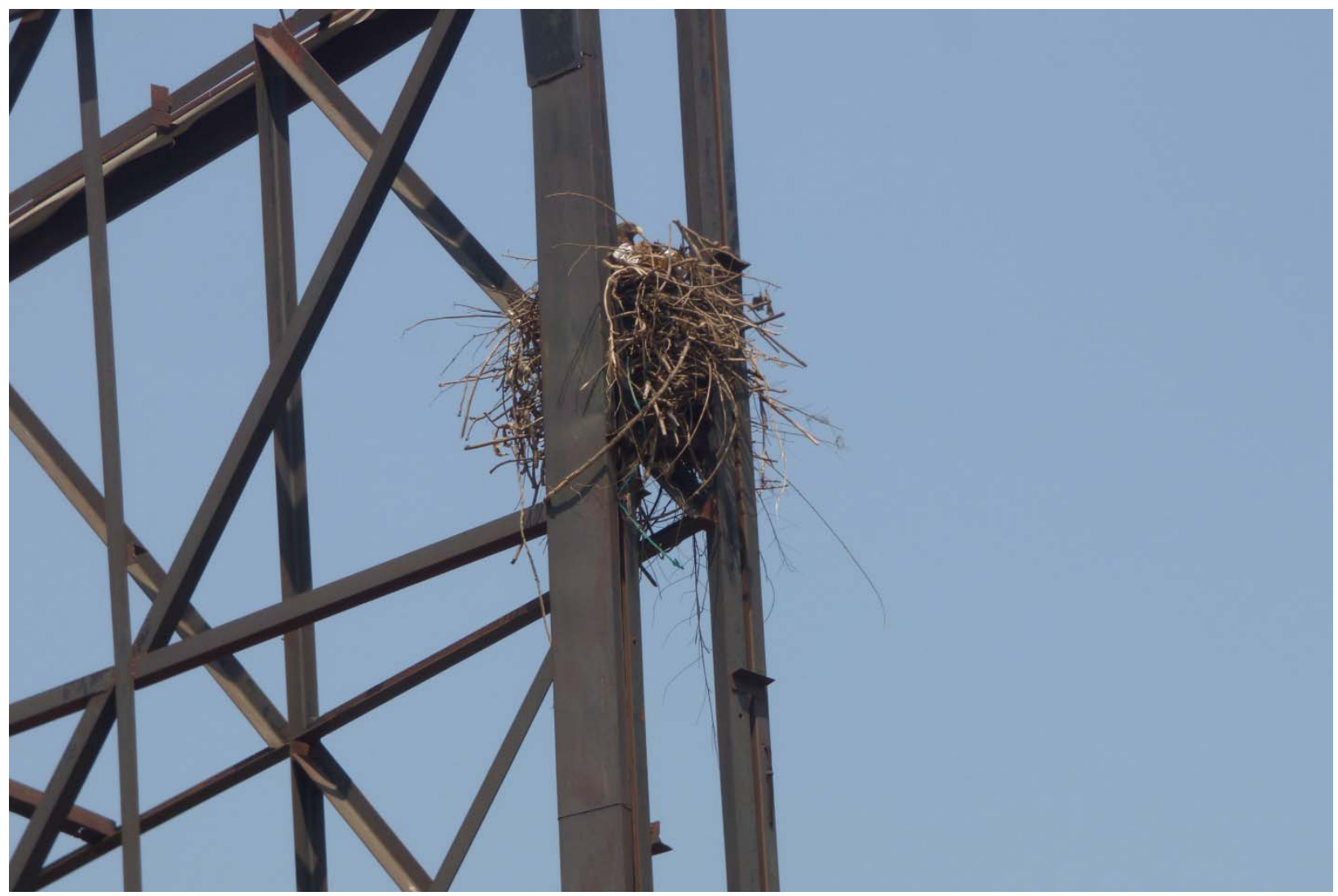

266 Figure 5: Yellow Billed Kite (Milvus aegyptius) brooding in a nest hung on a billboard 
bioRxiv preprint doi: https://doi.org/10.1101/2021.05.18.444309; this version posted May 18, 2021. The copyright holder for this preprint (which

was not certified by peer review) is the author/funder, who has granted bioRxiv a license to display the preprint in perpetuity. It is made available under aCC-BY-ND 4.0 International license.

268 Figure 6: Pied Crow (Corvus albus) hovering in the sky 
bioRxiv preprint doi: https://doi.org/10.1101/2021.05.18.444309; this version posted May 18, 2021. The copyright holder for this preprint (which

was not certified by peer review) is the author/funder, who has granted bioRxiv a license to display the preprint in perpetuity. It is made available under aCC-BY-ND 4.0 International license.

271 Figure 7: Yellow Billed Kite (Milvus aegyptius) hovering in the sky 
bioRxiv preprint doi: https://doi.org/10.1101/2021.05.18.444309; this version posted May 18, 2021. The copyright holder for this preprint (which was not certified by peer review) is the author/funder, who has granted bioRxiv a license to display the preprint in perpetuity. It is made available under aCC-BY-ND 4.0 International license.

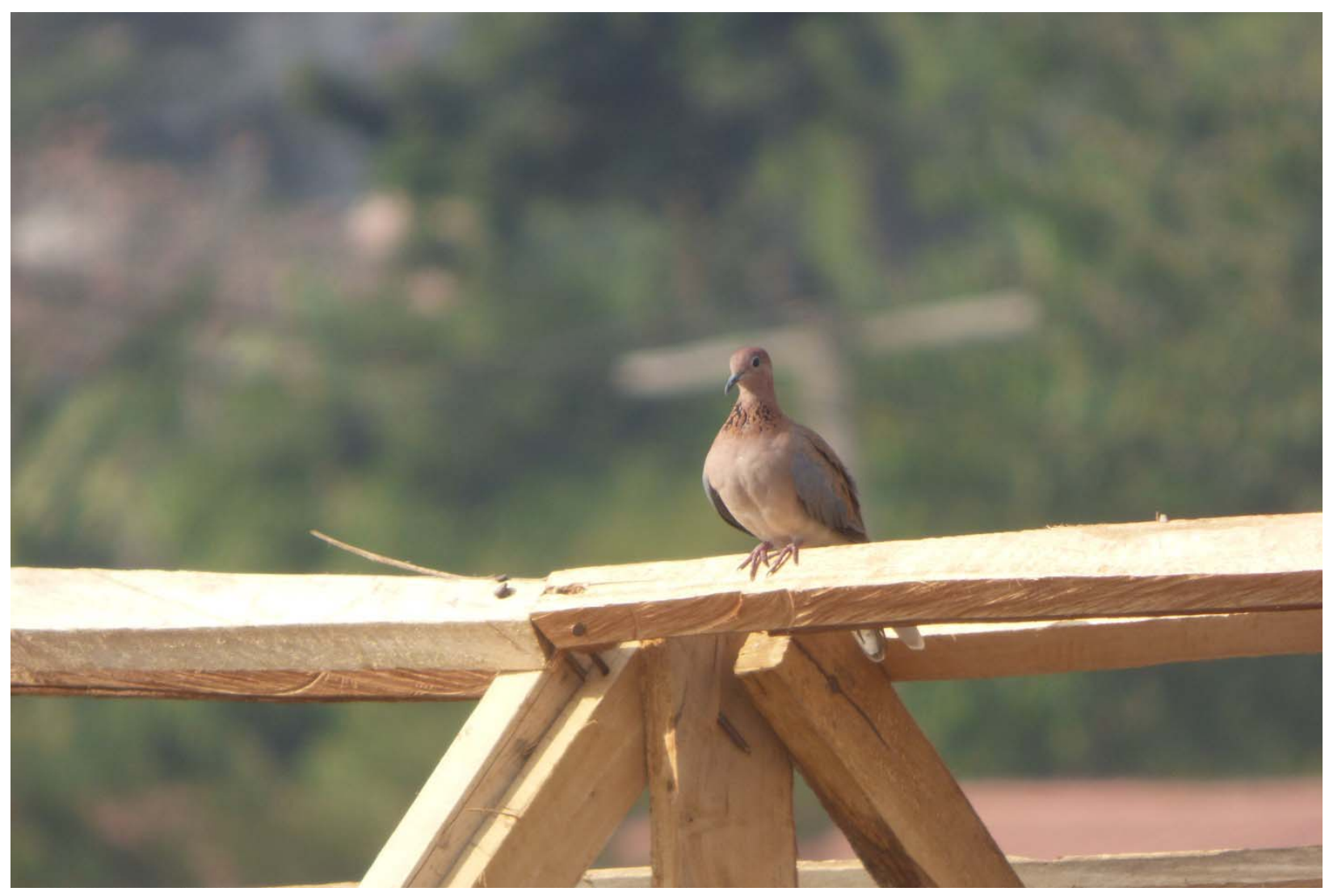

273 Figure 8: Laughing Dove (Streptopelia semitorquata) resting on a roof 
bioRxiv preprint doi: https://doi.org/10.1101/2021.05.18.444309; this version posted May 18, 2021. The copyright holder for this preprint (which

was not certified by peer review) is the author/funder, who has granted bioRxiv a license to display the preprint in perpetuity. It is made available under aCC-BY-ND 4.0 International license.

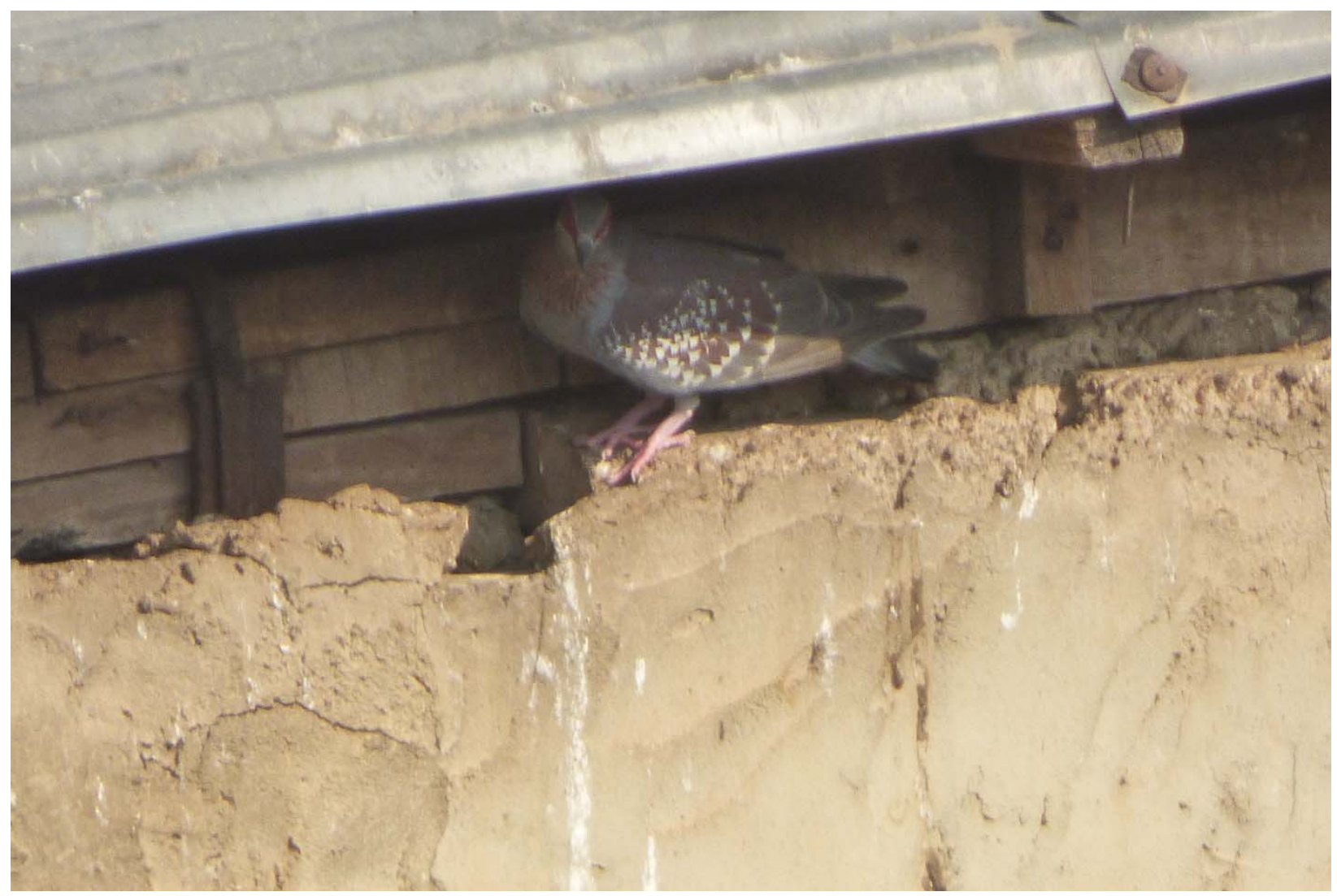

276 Figure 9: Speckled Pigeon (Columba guinea) in its roost 


\section{DISCUSSION}

278

279

280

281

282

283

284

285

286

287

288

289

290

291

292

293

294

295

296

297

298

299

300

301

302

303

304

305

The objective of this study was to examine the impacts of urbanization on bird species richness, abundance and the influence of habitat parameters on species richness and abundance in five selected urban local governments within Ibadan Metropolis. The researchers assessed the presence of birds using QGIS software application, of a uniform grid of 500 by 500 metres installed in some strategic areas in those local governments.

A total number of fifty-six (56) different species of birds were observed at the end of the assessment and those species were classified into Thirty (30) different family. Speckled Pigeon (Columba guinea) and Pied Crow (Corvus albus) had the highest number of individuals sighted, which were mostly found the roost around buildings' roof. The high numbers of C.albus might be as a result of the availability of refuse dumps littering the local governments visited. C.albus can be categorized as urban exploiters. These species have adapted to exploiting urban areas as seen in their close association with human habitation and dependence on human food subsidies (Labiran and Iwajomo 2018). All bird species were recorded within the surveyed grids. Few individuals of the endangered Grey Parrot Psittacus erithacus (BirdLife International 2019) were recorded during this survey. All other species recorded are currently categorized as Least Concerned under the IUCN Red List (IUCN 2018).

The Kruskal- Wallis H Test on the bird species richness revealed that the mean of Ibadan North Local Government has the highest and was rank first, subsequently followed by Ibadan South West, Ibadan South East, Ibadan North West and Ibadan North East Local Government respectively. The Post Hoc Test also reveal that there were no statistically significant differences in bird species richness in any of the Local Governments. This implies bird species richness does not vary in size of availability from one local government to another. Our study revealed that there were no difference in species richness which might probably due to the fact that all the selected local governments are urban centers and virtually the same ways of life are being practiced as they are all found in the same metropolis.

The Kruskal- Wahills H Test on bird species Abundance within the Local Government revealed that the mean of Ibadan North East has the highest mean rank, followed by Ibadan North, Ibadan South West, Ibadan South East and Ibadan North West Local Governments respectively. The test 
306

307

308

309

310

311

312

313

314

315

316

317

318

319

320

321

322

323

324

325

326

327

328

329

330

of statistics showed that there was no statistically significant difference in bird species abundance between the local governments as a whole. The post Hoc Test showed there were no statistical significant difference between each unit of the local government. This implies bird species abundance does not varies or different in size of availability from one local government to another.

The Test of Between-subjects Effects was carried out to assess the influence of habitat variables on bird species richness and bird species abundance within the metropolis. There was no statistical significant effects/interaction between all the habitat variables and species richness. This implies that habitat variables do not influence bird species richness in Ibadan Metropolis. Our observed results were different compared to Iwajomo et al. (2018), where bird species richness was significantly related to the percentage of ground cover and densities of shrubs and buildings in the study area.

Furthermore, the number of Paved roads and number of Vehicles exacted a significant effect on bird species abundance while others variables under consideration did not exact statistically significant effects on bird species abundance. Generally, bird abundance has been reported to increase in response to increase in urbanization (Tietze and Arise 2018) and this increase has been attributed to the availability of food subsidies and the reduction of predation pressure (Luck and Smallbone 2010).

Thus, this study serves as a baseline to foster future research in how bird diversity is affected by urban ecosystem in Nigeria. Since urban landscapes represent a mosaic of habitats providing diverse opportunities for birds, planning efforts should seek to create and maintain an appropriate balance of habitats that provide the most opportunities for the most species. Also, for successful urban bird conservation, there is need to address the conservation needs of birds, habitat potential of various urban landscape forms, and the needs and motivations of urban residents (Labiran and Iwajomo 2018). 


\section{ACKNOWLEDGEMENT}

I give all the glory, honor and adoration to the Almighty God who has proved His greatness and support to me beyond measures during and after this research work.

My sincere appreciation goes Prof. I. A. Ayodele for his fatherly advice and concern throughout the period of this research. Profound gratitude also goes to Dr. A. T. Adeyanju for his love, relentless effort and contributions towards the successful completion of this project.

My heartfelt gratitude also goes to my ever loving and supportive parents, $\mathrm{Mr}$ and $\mathrm{Mrs}$ Adegbola, for their spiritual, moral and financial contributions. I cannot forget my paternal aunt and her husband, Surveyor and Mrs Morawo for their immense support and love. Special regards also goes to Rev. Prof. R.S Babatunde and his family, whom have been a source of support and motivation for me, thanks for the prayers and contributions.

I cannot but give due praises and appreciation to my sisters Abike Oluwadamilola Adegbola, and Oluwamayowa Susan Adegbola, for their numerous contributions at several occasions throughout my stay in the University, may the good Lord bless you more and more. I give special thanks to my cousin and her husband- Engr Bolaji and Mrs Adeola Sadik for their numerous contributions. Oyebamiji Ayokuleyin Uthman, thank you for assisting me to make this work a successful one, I am forever indebted to you. I also acknowledge Azeez Grace Jesuferanmi for her contributions to this research work even at her inconvenience.

To my course mates, the FANTABULOUS CLASS OF 40, you all are the best, I wish us all greater heights and achievements in our future endeavors. The journey would not have been funfilled and interesting without you all. Thank you for all the good and ugly times we shared, your respect and support really means a lot. I have learnt a lot and I am very grateful. You all will always be remembered.

I also appreciate the following people: Mrs Temidayo Adeyanju, Mr Michael (Love Doctor) and Ibrahim Abdullahi and everybody who have been instrumental in making this project a success.

\footnotetext{
Thank you all and God bless you.
} 


\section{REFERENCES}

Areola A, Ikporukpo C. 2018. Social Ecology and Urban Green Spaces in Ibadan, Nigeria. Journal of Applied Sciences and Environmental Management 22:

Blair RB. 2001. Birds and butterflies along urban gradients in two ecoregions of the U.S. In Lockwood JL,McKinney ML,Eds.Biotic Homogenization.Norwell (MA):Kluwer; 33-56.

Birdlife International. (2019). Birdlife Data Zone. Retrieved December 23, 2019, from Partnership for nature and people website: http://www.birdlife.org/

Gatesire T, Nyiramana DA, Seburanga JL, Mirville MO. 2015. Bird Diversity and Distribution in relation to Urban Landscape Types in Northern Rwanda. Available at http://www.hindawi.com/journals/tswj/2014/157824/ [Accessed on 20 December 2019]

Hostetler M. 1997. Scale, birds and human decisions: A potential for integrative research in urban ecosystems. Lanscape and Urban Planning 45: 15-19.

Iwajomo S. 2018. Patterns in Bird Species Richnes and Abundance in the Univeristy of Lagos, Akoka Campus. Journal of Research in Forestry, Wildlife and Environmental; 10

Labiran J, Iwajomo S. 2018. Factors Influencing Bird Species Richness and Abundance in Surulere Local Government Area of Lagos State, Nigeria. Proceedings of 6th NSCB Biodiversity Conference: Uniuyo: pp 183 - 188.

Lin YP, Chang CR, Chu HJ, Cheng BY. 2011. Identifying the spatial mixture distribution of bird diversity across urban and suburban areas in the metropolis: A case study in Taipei Basin of Taiwan. Landscape and Urban Planning 102: 156-163. 
Luck GW, Smallbone L. 2010. Species diversity and urbanization: patterns, drivers and implications. Cambridge University Press 39: 256-289.

Magle SB, Hunt VM, Vernon M, Crooks KR. 2012. Urban wildlife research: Past, present and future. Biological Conservation 155: 22-32.

McCaffrey RE, Mannan RW. 2012. How scale influences birds' responses to habitat features in urban residential areas. Landscape and Urban Planning 105: 274-280.

McKinney ML. 2002. Urbanization, biodiversity and conservation. Bioscience 52: 883-890.

Popoola A, Wahab B. 2018. Climate-induced problems and adaptation strategies of urban farmers in Ibadan. Ethopian Journal of Environmental Studies \& Management 11: 31-42.

Salami RO, Von Meding JK, H Giggins. 2016. Assesing habitats of vulnerability in African Cities: A case of poverty outing in Ibadan Metropolis, Nigeria.

Sol D, Gonza lez-Lagos C, Moreira D, Maspons J, L, O. 2014. Urbanisation tolerance and the loss of avian diversity. Ecology Letters 17: 942-950.

Tietze DT (eds), Arise HT. 2018. Bird Species: How they arise, modify and vanish. Switzerland: Springer.

Walker JS, Balling RC, Briggs JM, Katti M, Warren PS, Wentz EA. 2008. Birds of a feather: Interpolating distribution patterns of urban birds. Computers, Environment and Urban Systems 32: 19-28.

Wolff PJ, Degregorio BA, Rodriguez-Cruz V, Mulero-Oliveras E, Sperry JH. 2018. Bird community assemblage and distribution in a tropical, urban ecosystem of Puerto Rico. 
bioRxiv preprint doi: https://doi.org/10.1101/2021.05.18.444309; this version posted May 18, 2021. The copyright holder for this preprint (which was not certified by peer review) is the author/funder, who has granted bioRxiv a license to display the preprint in perpetuity. It is made available under aCC-BY-ND 4.0 International license. 
bioRxiv preprint doi: https://doi.org/10.1101/2021.05.18.444309; this version posted May 18, 2021. The copyright holder for this preprint (which

was not certified by peer review) is the author/funder, who has granted bioRxiv a license to display the preprint in perpetuity. It is made available under aCC-BY-ND 4.0 International license.

403 Keywords

404 Introduction

405 Materials and Methods

406 Results

407 Discussion

408 Acknowledgement

409 References

410 Tables

411 Appendix 
415 1a Descriptive Statistics on Species Richness

$416 \quad 1 b \quad$ Kruskal- Wallis H Test on Species Richness

417 1c Post Hoc Test on Bird Species Richness

$418 \quad 2 \mathrm{a} \quad$ Descriptive Statistics on Species Abundance

4213 Test of between- Subjects Effects on Species Richness and habitat variables

4224 Test of between- Subjects Effects on Species Abundance and Habitat variables 


\section{SPECIES OF BIRDS OBSERVED AND THEIR GROUPING}

\begin{tabular}{|c|c|c|c|}
\hline & Family & Scientific Name & Species \\
\hline \multicolumn{4}{|l|}{425} \\
\hline 426 & Apodidae & Apus affinis & Little Swift \\
\hline 427 & Apodidae & Cypsiurus parvus & African Palm Swift \\
\hline 428 & Apodidae & Telacanthura ussheri & Mottled Spinetail \\
\hline 429 & Accipitridae & Milvus migrans & Yellow Billed Kite \\
\hline 430 & Alcedinidae & Ceyx pictus & African Pygmy Kingfisher \\
\hline 431 & Alcedinidae & Alcedo cristata & Malachite Kingfisher \\
\hline 432 & Alcedinidae & Halcyon senegalensis & Woodland Kingfisher \\
\hline 433 & Alcedinidae & Halcyon malimbica & Blue-breasted Kingfisher \\
\hline 434 & Ardeidae & Bubulcus Ibis & Western Cattle Egret \\
\hline 435 & Ardeidae & Ardea purpurea & Grey Heron \\
\hline 436 & Bucerotidae & Tockus fasciatus & African Pied Hornbill \\
\hline 437 & Bucerotidae & Tockus nasutus & African Grey Hornbill \\
\hline 438 & Cisticolidae & Cisticola erythrops & Red-faced Cisticola \\
\hline 439 & Columbidae & Streptopelia senegalensis & Laughing dove \\
\hline 440 & Columbidae & Streptopelia semitorquata & Red-eyed Dove \\
\hline 441 & Columbidae & Tutur afer & Blue-spotted Wood Dove \\
\hline 442 & Columbidae & Columba guinea & Speckled Pigeon \\
\hline 443 & Coraciidae & Eurystomus glaucurus & Broad-billed Roller \\
\hline
\end{tabular}


444 Corvidae

445 Corvidae

446 Cuculidae

447 Cuculidae

448 Charadriidae

449 Dicruridae

$450 \quad$ Estrildidae

$451 \quad$ Estrildidae

452 Estrildidae

453 Falconidae

454 Falconidae

455 Hirundinidae

456 Hirundinidae

457 Hirundinidae

$458 \quad$ Hirundinidae

459

460

461

Meropidae

462 Musophagidae

463 Motacillidae

464 Motacillidae
Corvus albus

Ptilostomus afer

Centropus senegalensis

Centropus monachus

Vanellus spinosus

Dicrurus adsimilis

Estrilda melpoda

Logonosticta rufopicta

Spermestes cucullatus

Falco tinnuculus

Falco ardosiaceus

Hirundo aethiopica

Hirundo senegalensis

Hirundo rustica

Hirundo fuligula

Corvinella corvina

Merops bullockoides

Merops persicus

Crinifer piscator

Motacilla aguimp

Anthus leucophrys
Pied Crow

Piacpiac

Senegal Coucal

Blue-headed Coucal

Spur-winged Lapwing

Forked-tailed Drongo

Orange-cheeked Waxbill

Bar-breasted Fire Finch

Bronze Mannikin

Common Kestrel

Grey Kestrel

Ethiopian Swallow

Mosque Swallow

Barn Swallow

Rock Martin

Yellow-billed Shrike

White-fronted Bee Eater

Blue-cheeked Bee-Eater

Western Plantain Eater

African Pied Wagtail

Plain-backed Pipit 


\begin{tabular}{|c|c|c|c|}
\hline 465 & Nectariniidae & Cinnyris chloropygius & Olive Bellied Sunbird \\
\hline 466 & Nectariniidae & Cinnyris coccinigastrus & Splendid Sunbird \\
\hline 467 & Nectariniidae & Cinnyris Superbus & Superb Sunbird \\
\hline 468 & Nectariniidae & Hedydipna collaris & Collared Sunbird \\
\hline 469 & Nectariniidae & Cyanomitra olivacea & Olive Sunbird \\
\hline 470 & Phasianiidae & Francolinus bicalcaratus & Double-spurred Francolin \\
\hline 471 & Phoeniculidae & Malimbus rubricollis & Red-headed Malimbe \\
\hline 472 & Passridae & Passer griseus & Northern Grey-headed Sparrow \\
\hline 473 & Phoeniculidae & Phoeniculus purpureus & Green Wood-hoopoe \\
\hline 474 & Platysteiridae & Platysteira cyanea & Common Wattle-eye \\
\hline 475 & Ploceidae & Ploceus cucullatus & Village Weaver \\
\hline 476 & Pycnonotidae & Pycnonotus barbatus & Common Bulbul \\
\hline 477 & Psittacidae & Poicephalus senegalus & Senegal Parrot \\
\hline 478 & Sturnidae & Lamprotornis purpure us & Purple Glossy Starling \\
\hline 479 & Sturnidae & Onychognathus fulgidus & Forest Chestnut-winged Starling \\
\hline 480 & Sylviidae & Camaroptera brachyuran & Grey-backed Camaroptera \\
\hline 481 & Sylviidae & Prinia subflava & Tawny-flanked Prinia \\
\hline 482 & Turtidae & Turdus pelios & African Thrush \\
\hline
\end{tabular}


